Bangladesh J. Plant Taxon. 28(2): 295-309, 2021 (December)

(C) 2021 Bangladesh Association of Plant Taxonomists

DOI: https://doi.org/10.3329/bjpt.v28i2.57128

\title{
COMPARATIVE ANATOMICAL CHARACTERISTICS OF THE SUBGENUS CYANUS (MILL.) HAYEK (ASTERACEAE) IN TURKEY
}

\author{
Burcu Yilmaz ÇitaK*, Emrah Şirin, Hüseyin Dural and Kuddisi ErtuĞRUl \\ Department of Biology, Faculty of Science, University of Selçuk, Konya, Turkey
}

Keywords: Morphoanatomy; Cyanus; Numerical analysis; Plant systematics.

\begin{abstract}
The identification of species based on anatomical characters is valuable to investigate their taxonomic status, phylogeny and understand their autoecology. The current study analysed the stem and leaf properties of 20 species of the subgenus Cyanus (Mill.) Hayek in Turkey. The Cyanus species exhibited xeromorphic anatomical features, such as tight palisade parenchyma and induced spongy parenchyma, which indicated adaptations to the arid soil and a forest ecosystem in which they occurred, as well as to high light intensity and precipitation. Anatomical features such as the midrib shape and number of vascularization patterns differed among the species. Similar anatomical characters were analysed for the investigated species. These properties can provide an important database for future studies including the phylogeny within the subgenus Cyanus.
\end{abstract}

\section{Introduction}

The group Cyanus (Mill.) Hayek of the family Asteraceae was first described as a genus (Miller, 1754), and then later reduced to a section of the genus Centaurea L., a position that was accepted by some taxonomists (Candolle, 1838; Bentham, 1873; Stefanov, and Gheorghiev, 1931; Wagenitz, 1975). However, by some other taxonomists, it was recognized as a subgenus of Centaurea based on molecular evidence (Susanna and Garcia-Jacas, 2009; Hilpold et al., 2014a, 2014b). However, some botanists also recognized Cyanus as a separate genus based on morphological evidence (Soják, 1972; Greuter, 2003, 2008; Hellwig, 2004; Wagenitz, 2006; Olšavská et al., 2009, 2011; Stoyanov, 2016; Negaresh, 2018).

In Turkey, the subgenus Cyanus was rearranged as a subgenus (Ertuğrul et al., 2018) as a result of molecular studies (Susanna and Garcia-Jacas, 2009; Hilpold et al., 2014a, b).

The florets of the subgenus Cyanus are blue or purplish (rarely creamy or pale pinkish), which are extremely unusual colours in the subtribe Centaureinae (Boršić et al., 2011). The appendages that are decurrent and not ending with mucro are characteristic for Cyanus, and their involucrum and leaf features are effective in species distinction (Wagenitz, 1975).

Anatomical studies can provide useful characters that could aid in the identification of problematic species, and also establish their taxonomical relationships (Metcalfe and Chalk, 1957; Janaćković et al., 2019a,b; Janaćković et al., 2019b). Although there have been many studies on the anatomy of Centaurea species (Metcalfe and Chalk, 1950; Esau, 1977; Metcalfe and Chalk, 1979; Uysal, 1991; Bhattacharya and Johri, 1998; Kaya et al., 2000; Celik et al., 2005; Uysal et al., 2005; Celik et al., 2008; Altundağ and Gürdal, 2009; Aydin et al., 2013; Özcan, 2013; Taşar et al., 2018; Aydın et al., 2019), there are very few studies regarding Cyanus species (Çakırlar et al., 2005; Ozcan et al., 2014; Ozcan, 2018).

Examining subgenus Cyanus species to identify their anatomical characteristics, clarifying the systematic value of their anatomical characteristics by way of numerical analysis, and contributing to the systematic position of the examined taxa were the main objectives herein.

\footnotetext{
*Corresponding author, E-mail: burcuyilmaz@ selcuk.edu.tr
} 


\section{Materials and Methods}

In this study 20 species of subgenus Cyanus in Turkey have been investigated (Table 1). The voucher specimens of each species, collected from at least five individuals, were stored in the Herbarium of Konya (KNYA). At least five fully-grown leaves and the middle parts of the stems were used in the analysis. Only sections of $C$. lanigera were taken from the herbarium specimen.

All procedures were performed at the Plant Anatomy Laboratory, Department of Biology, Selçuk University, Konya, Turkey, with either herbarium material or material fixed in 70\%. Crosssections of the stem, leaf blade and midrib were obtained using a rotary microtome. The paraffin method was applied and the parts of stem and leaf were treated through alcohol and xylene series. The anatomical tissues were stained with safranin-fast green, which was used as an established method (Johansen, 1940). The vascularization patterns of the stems and leaves, parenchyma pattern, and arrangement of the midrib vascular system were analysed. The microphotographs of the anatomical slides were obtained using a Canon EOS450D digital camera (Ota City, Tokyo, Japan) attached to Leica 1000 DM light microscope (Wetzlar, Germany).

A total of nine anatomical characters (six quantitative and three qualitative) were measured $(\mu \mathrm{m})$ or scored using Kameram v.21 analysis system software (Argenit, Istanbul, Turkey) (Tables 2 and 3). A data matrix was set using the recorded qualitative and quantitative characters. Based on the anatomical characters, the coefficients of correlation among the 20 species were determined and these species were grouped using the clustering analysis method (unweighted pair group method with arithmetic mean (UPGMA), dissimilarity, standardized variables). The clustering analysis was based on Gower's (1971) general coefficient similarity (Sneath and Sokal, 1973), which was used directly with a mixture of character types (binary, qualitative, and quantitative. Untransformed, centered, and unstandardized data were used to create a covariance matrix. MVSP 3.22 software (Kovach Computing Services, Anglesey, Wales) was used for all of the computations.

Table 1. Locality information of the investigated taxa of Cyanus subgenus.

\begin{tabular}{|c|c|c|c|}
\hline Acronym & Collection number & Species & Locality \\
\hline $\mathrm{C} 1$ & **EŞ-574-MŞ & $\begin{array}{l}\text { Centaurea reuteriana Boiss. var. } \\
\text { reuteriana }\end{array}$ & $\begin{array}{l}\text { C2 Muğla: Köyceğiz, Sandras mountain, } \\
1763 \text { m, 29.06.2015 }\end{array}$ \\
\hline \multirow[t]{3}{*}{$\mathrm{C} 2 *$} & **EŞ-554-MŞ & $\begin{array}{l}\text { C. reuteriana Boiss. var. phrygia } \\
\text { Bornm. }\end{array}$ & $\begin{array}{l}\text { B3 Afyon: Sultandağları, } 1850 \mathrm{~m} \text {, } \\
\text { 21.05.2015 }\end{array}$ \\
\hline & EŞ-582-MY & $\begin{array}{l}\text { C. reuteriana Boiss. var. phrygia } \\
\text { Bornm. }\end{array}$ & $\begin{array}{l}\text { A4 Karabük: Keltepe, step, } 1800 \text { m, } \\
\text { 09.07.2015 }\end{array}$ \\
\hline & EŞ-562-MŞ & $\begin{array}{l}\text { C. reuteriana } \text { Boiss. var. phrygia } \\
\text { Bornm. }\end{array}$ & $\begin{array}{l}\text { C3 Isparta: Davraz Dağı, stony places, } 1800 \\
\mathrm{~m}, 16.06 .2015\end{array}$ \\
\hline $\mathrm{C} 3 *$ & **EŞ-659-MŞ & C. lanigera DC. & $\begin{array}{l}\text { B5 Aksaray: Hasan mountain, } 1979 \text { m, } \\
\text { 29.06.2016 }\end{array}$ \\
\hline \multirow[t]{2}{*}{$\mathrm{C} 4$} & **EŞ-668-MŞ & C. nigrofimbria (K. Koch) Sosn. & $\begin{array}{l}\text { A8 Trabzon: Çaykara, Soğanlı mountain, } \\
2300 \mathrm{~m}, 12.07 .2016\end{array}$ \\
\hline & EŞ-595-AG,HG & C. nigrofimbria (K. Koch) Sosn. & $\begin{array}{l}\text { A8 Trabzon: Çaykara: North of Soğanlı } \\
\text { Mountain, steppe, } 2300 \mathrm{~m}, 12.07 .2016\end{array}$ \\
\hline $\mathrm{C} 5$ & **EŞ-642-MŞ & C. woronowii & $\begin{array}{l}\text { A9 Artvin: Ardanuç, } 2 \mathrm{~km} \text { to Rabat Church, } \\
1273 \mathrm{~m}, 11.06 .2016\end{array}$ \\
\hline C6* & **EŞ-656-MŞ & $\begin{array}{l}\text { C. eflanensis (Kaya \& Bancheva) } \\
\text { Şirin \& Ertuğrul }\end{array}$ & $\begin{array}{l}\text { A4 Karabük: Bartın-Safranbolu road, } 1078 \\
\text { m, 15.06.2016 }\end{array}$ \\
\hline
\end{tabular}


Table 1 Contd.

\begin{tabular}{|c|c|c|c|}
\hline Acronym & Collection number & Species & Locality \\
\hline $\mathrm{C} 7$ & **EŞ-605-MŞ & C. thirkei Sch. Bip. & $\begin{array}{l}\text { B1 Manisa: Spil Mountain, Merdivencik, } P \text {. } \\
\text { Nigra openings, } 951 \mathrm{~m}, 30.04 .2016\end{array}$ \\
\hline \multirow[t]{2}{*}{$\mathrm{C} 8$} & EŞ-591-MŞ & $\begin{array}{l}\text { C. cheiranthifolia Willd. var. } \\
\text { cheiranthifolia }\end{array}$ & $\begin{array}{l}\text { A9 Ardahan: Çıldır-Aktaş road, } 2100 \mathrm{~m} \text {, } \\
\text { 14.08.2015 }\end{array}$ \\
\hline & **EŞ-672-MŞ & $\begin{array}{l}\text { C. cheiranthifolia Willd. var. } \\
\text { cheiranthifolia }\end{array}$ & $\begin{array}{l}\text { A9 Ardahan: Hanak, Aydere Village, step, } \\
2326 \mathrm{~m}, 14.07 .2016 .\end{array}$ \\
\hline C9 & **EŞ-643-MŞ & $\begin{array}{l}\text { C. cheiranthifolia Willd. var. } \\
\text { purpurascens (DC.) Wagenitz }\end{array}$ & $\begin{array}{l}\text { A9 Ardahan: Değirmenli village, } 2287 \mathrm{~m} \text {, } \\
\text { 11.06.2016 }\end{array}$ \\
\hline \multirow[t]{2}{*}{$\mathrm{C} 10$} & **EŞ-622-MŞ & C. bourgaei Boiss. & C4 İçel: Mut, 1561 m, 15.05.2016 \\
\hline & EŞ-572-MŞ & C. bourgaei Boiss. & $\begin{array}{l}\text { C3 Antalya: Elmalı, Kızlar Sivrisi dağcılar } \\
\text { şenlik alanı, road sides, } 1900 \text { m, 29.06.2015 }\end{array}$ \\
\hline \multirow[t]{3}{*}{$\mathrm{C} 11$} & EŞ-577-MŞ & C. pichleri Boiss. subsp. pichleri & A5 Amasya: Merzifon, 1502 m, 07.07.2015 \\
\hline & EŞ-567-MŞ & C. pichleri Boiss. subsp. pichleri & $\begin{array}{l}\text { C2 Antalya: Korkuteli, Kirkpinar Plateau, } \\
1600 \text { m, 17.06.2015 }\end{array}$ \\
\hline & **EŞ-535-MŞ & C. pichleri Boiss. subsp. pichleri & $\begin{array}{l}\text { C3 Isparta: Davraz Mountain, steppe, } 1600 \\
\mathrm{~m}, 12.05 .2015\end{array}$ \\
\hline \multirow[t]{6}{*}{$\mathrm{C} 12 *$} & **EŞ-635-MŞ & $\begin{array}{l}\text { C. pichleri Boiss. subsp. } \\
\text { extrarosularis (Hayek \& Siehe) } \\
\text { Wagenitz }\end{array}$ & $\begin{array}{l}\text { C5 Niğde: Demirkazık Mountain, } 1849 \text { m, } \\
02.06 .2016\end{array}$ \\
\hline & EŞ-576-MŞ & $\begin{array}{l}\text { C. pichleri Boiss. subsp. } \\
\text { extrarosularis (Hayek \& Siehe) } \\
\text { Wagenitz }\end{array}$ & $\begin{array}{l}\text { B2 Kütahya: Murat Mountain, near summit, } \\
\text { Pinus nigra openings, } 1850 \mathrm{~m}, 01.07 .2015\end{array}$ \\
\hline & EŞ-613-MŞ & $\begin{array}{l}\text { C. pichleri Boiss. subsp. } \\
\text { extrarosularis (Hayek \& Siehe) } \\
\text { Wagenitz }\end{array}$ & $\begin{array}{l}\text { B3 Eskişehir: Kütahya - Eskişehir road, } \\
\text { steppe, } 820 \mathrm{~m}, 03.05 .2016\end{array}$ \\
\hline & EŞ-616-MŞ & $\begin{array}{l}\text { C. pichleri Boiss. subsp. } \\
\text { extrarosularis (Hayek \& Siehe) } \\
\text { Wagenitz }\end{array}$ & $\begin{array}{l}\text { B5 Kayseri: Yahyalı - Aladağ road, red- } \\
\text { brown soils, } 1727 \text { m, 05.05.2016 }\end{array}$ \\
\hline & EŞ-568-MŞ & $\begin{array}{l}\text { C. pichleri Boiss. subsp. } \\
\text { extrarosularis (Hayek \& Siehe) } \\
\text { Wagenitz }\end{array}$ & $\begin{array}{l}\text { C4 Konya: Konya-Beyşehir road, turnout of } \\
\text { Ayışığı At Çiftliği, steppe, } 1270 \text { m, } \\
27.06 .2015\end{array}$ \\
\hline & EŞ-623-MŞ & $\begin{array}{l}\text { C. pichleri Boiss. subsp. } \\
\text { extrarosularis (Hayek \& Siehe) } \\
\text { Wagenitz }\end{array}$ & $\begin{array}{l}\text { C5Niğde: Niğde/Adana; Aladağ, Narpuz } \\
\text { Boğazı, steppe, } 2224 \text { m, 16.05.2016 }\end{array}$ \\
\hline \multirow[t]{3}{*}{$\mathrm{C} 13$} & **EŞ-583-MŞ & $\begin{array}{l}\text { C. triumfettii subsp. axillaris } \\
\text { (Č́lak.) Stef. \& T. Georgiev }\end{array}$ & B2 Kütahya: Akdağ, 1610 m, 14.05.2016 \\
\hline & EŞ-579-MŞ & $\begin{array}{l}\text { C. triumfettii subsp. axillaris } \\
\text { (Čelak.) Stef. \& T. Georgiev }\end{array}$ & $\begin{array}{l}\text { A4 Bolu: Mengen, } 1 \mathrm{~km} \text { to Arak Village, } P \text {. } \\
\text { nigra forest, } 812 \mathrm{~m}, 08.07 .2015\end{array}$ \\
\hline & EŞ-548-MŞ & $\begin{array}{l}\text { C. triumfettii subsp. axillaris } \\
\text { (Čelak.) Stef. \& T. Georgiev }\end{array}$ & A4 Çankırı: Step, 750 m, 20.05.2015 \\
\hline \multirow[t]{2}{*}{$\mathrm{C} 14$} & **EŞ-645-MŞ & C. huetii Boiss. & $\begin{array}{l}\text { A9 Ardahan: Çıldır, } 1 \mathrm{~km} \text { to Gökbelen } \\
\text { Village, sides of fields, } 1991 \mathrm{~m}, 12.06 .2016\end{array}$ \\
\hline & EŞ-666-MŞ & C. huetii Boiss. & $\begin{array}{l}\text { B7 Sivas: Divriği, Göl Mountain, summit, } \\
\text { steppe, } 1926 \text { m, 01.07.2016 }\end{array}$ \\
\hline \multirow[t]{3}{*}{$\mathrm{C} 15^{*}$} & **EŞ-618-MŞ & C. mathiolifolia Boiss. & $\begin{array}{l}\text { C2 Denizli: Honaz Mountain, } 1829 \mathrm{~m} \text {, } \\
\text { 12.05.2016 }\end{array}$ \\
\hline & EŞ-549-MŞ & C. mathiolifolia Boiss. & $\begin{array}{l}\text { B3 Afyon: Sultandağ } 1 \text {, Dereçine-Büyükyayla } \\
\text { road, road sides, } 1350 \mathrm{~m}, 21.05 .2015\end{array}$ \\
\hline & EŞ-599-MŞ & C. mathiolifolia Boiss. & $\begin{array}{l}\text { C2 Burdur: from Tefenni to Korkuteli, stony } \\
\text { places, } 1351 \mathrm{~m}, 28.04 .2016\end{array}$ \\
\hline
\end{tabular}


Table 1 Contd.

\begin{tabular}{|c|c|c|c|}
\hline Acronym & Collection number & Species & Locality \\
\hline & EŞ-561a-MŞ & C. mathiolifolia Boiss. & $\begin{array}{l}\text { C2 Isparta: Davraz Mountain, stony places, } \\
1800 \mathrm{~m}, 16.06 .2015\end{array}$ \\
\hline & EŞ-564-MŞ & C. mathiolifolia Boiss. & $\begin{array}{l}\text { C2 Isparta: Davraz Mountain, around ski } \\
\text { resort, steppe, } 1600 \mathrm{~m}, 16.06 .2015\end{array}$ \\
\hline $\mathrm{C} 16^{*}$ & **EŞ-614-MŞ & C. germanicopolitana Bornm. & $\begin{array}{l}\text { A4 Çankır1: Eldivan, before } 3 \mathrm{~km} \text { to } \\
\text { Oğlaklı Village, road sides, } 854 \mathrm{~m} \text {, } \\
\text { 04.05.2016 }\end{array}$ \\
\hline \multirow[t]{5}{*}{$\mathrm{C} 17$} & **EŞ-547-MŞ & C. depressa Bieb. & $\begin{array}{l}\text { A4 Çankırı: Hacı Ali Dinlenme Tesisi, road } \\
\text { sides, } 700 \mathrm{~m}, 20.05 .2015\end{array}$ \\
\hline & EŞ-637-MŞ & C. depressa Bieb. & $\begin{array}{l}\text { A5 Amasya: Akdağ, near summit, road } \\
\text { sides, } 1003 \mathrm{~m}, 09.06 .2016\end{array}$ \\
\hline & EŞ-545-MŞ & C. depressa Bieb. & $\begin{array}{l}\text { B3 Afyon: Sinanpaşa, Düzağaç Town, road } \\
\text { sides, } 1150 \mathrm{~m}, 15.05 .2015\end{array}$ \\
\hline & EŞ-557-MŞ & C. depressa Bieb. & $\begin{array}{l}\text { B4 Ankara: Hacı Hasan Village, 'Sevgi } \\
\text { çiçeği' protected area, fallow places, } 950 \\
\text { m, 28.05.2015 }\end{array}$ \\
\hline & EŞ-541-MŞ & C. depressa Bieb. & C2 Denizli: $950 \mathrm{~m}, 13.05 .2015$ \\
\hline \multirow[t]{3}{*}{$\mathrm{C} 18$} & **EŞ-598-MŞ & C. pinardii Boiss. & $\begin{array}{l}\text { C3 Burdur: İlyas village, } 870 \mathrm{~m} \text {, } \\
\text { 28.04.2016 }\end{array}$ \\
\hline & EŞ-603-MŞ & C. pinardii Boiss. & $\begin{array}{l}\text { B2 Uşak: Southwest of Uşak, near Karabol } \\
\text { stream, steppe, } 580 \mathrm{~m}, 29.04 .2016\end{array}$ \\
\hline & EŞ-602-MŞ & C. pinardii Boiss. & $\begin{array}{l}\text { B3 Afyon: Dazkırı, Sarıkavak Village, edge } \\
\text { of fields, } 864 \mathrm{~m}, 29.04 .2016\end{array}$ \\
\hline $\mathrm{C} 19^{*}$ & **EŞ-560-MŞ & $\begin{array}{l}\text { C. tchihatcheffii Fisch. \& C. A. } \\
\text { Mey. }\end{array}$ & B3 Afyon: Dazkır1, 864 m, 15.06.2015 \\
\hline $\mathrm{C} 20$ & **EŞ-604-MŞ & C. cyanus $\mathrm{L}$. & $\begin{array}{l}\text { B1 Manisa: Spil Mountain, } 647 \text { m, } \\
\text { 30.04.2016 }\end{array}$ \\
\hline
\end{tabular}

*Endemic taxa, ** Selected taxa.

Table 2. Anatomical traits used in statical analysis of Cyanus subgenus.

\begin{tabular}{lll}
\hline Vegetative organ & Acronyms & Definition of anatomical traits \\
\hline Stem & A1 & Number of vessels \\
& A2 & Diameter of pith cells \\
Leaf & A3 & Width of collenchyma \\
& A4 & Sclerenchyma cells on phloem \\
& A5 & Mesophyll type \\
A6 & Mesophyll thickness \\
A7 & Length of palisade cells \\
A8 & Width of palisade cells \\
& A9 & Width of spongy parenchyma/mesophyll \\
& A10 & Row of palisade tissue \\
A11 & Width of spongy parenchyma \\
A12 & The shape of midrib (triangular: 0, linear: 1, oval:2, v-shaped:3) \\
\hline
\end{tabular}


Table 3. The anatomical measurements and observations of Cyanus subgenus.

\begin{tabular}{|c|c|c|c|c|c|c|c|c|c|c|c|c|}
\hline $\begin{array}{l}\text { Species/Anatomical } \\
\text { characters }\end{array}$ & A1 & $\mathrm{A} 2$ & $\mathrm{~A} 3$ & A4 & A5 & A6 & A7 & A8 & A9 & A10 & A11 & A12 \\
\hline $\begin{array}{l}\text { C. reuteriana var. } \\
\text { reuteriana }\end{array}$ & 18 & 93.51 & 146.43 & 1 & 0 & 690.37 & 67.39 & 18.45 & 0.12 & 3 & 88.52 & 2 \\
\hline $\begin{array}{l}\text { C. reuteriana var. } \\
\text { phrygia }\end{array}$ & 20 & 82.19 & 57.74 & 1 & 0 & 230.76 & 40.85 & 12.90 & 0.46 & 3 & 108.44 & 1 \\
\hline C. lanigera & 18 & 38.25 & 128.43 & 1 & 0 & 152.79 & 18.56 & 7.04 & 0.27 & 2 & 42.41 & 2 \\
\hline C. nigrofimbria & 19 & 80.71 & 79.80 & 1 & 1 & 203.39 & 31.80 & 20.64 & 0.31 & 2 & 63.35 & 0 \\
\hline C. woronowii & 20 & 61.58 & 125.14 & 0 & 1 & 105.23 & 23.35 & 13.36 & 0.28 & 2 & 29.71 & 0 \\
\hline C. eflanensis & 16 & 76.53 & 103.4 & 1 & 0 & 227.13 & 32.04 & 16.55 & 0.28 & 2 & 65.81 & 2 \\
\hline C. thirkei & 20 & 40.58 & 97.09 & 0 & 0 & 209.63 & 25.34 & 11.07 & 0.21 & 3 & 44.63 & 0 \\
\hline $\begin{array}{l}\text { C. cheiranthifolia var. } \\
\text { cheiranthifolia }\end{array}$ & 26 & 114.73 & 175.63 & 1 & 0 & 202.09 & 34.55 & 16.22 & 0.28 & 2 & 58.53 & 0 \\
\hline $\begin{array}{l}\text { C. cheiranthifolia var. } \\
\text { purpurascens }\end{array}$ & 24 & 82.23 & 88.72 & 1 & 0 & 421.05 & 60.37 & 24.16 & 0.24 & 2 & 103.02 & 1 \\
\hline C. bourgaei & 13 & 50.05 & 62.46 & 1 & 0 & 262.81 & 48.92 & 14.49 & 0.17 & 2 & 45.41 & 2 \\
\hline $\begin{array}{l}\text { C. pichleri subsp. } \\
\text { pichleri }\end{array}$ & 19 & 57.64 & 116.33 & 1 & 0 & 165.38 & 26.22 & 10.82 & 0.27 & 3 & 44.76 & 0 \\
\hline $\begin{array}{l}\text { C. pichleri subsp. } \\
\text { extrarosularis }\end{array}$ & 16 & 65.31 & 111.99 & 1 & 0 & 231.94 & 29.23 & 14.55 & 0.22 & 2 & 52.53 & 3 \\
\hline $\begin{array}{l}\text { C. triumfettii subsp. } \\
\text { axillaris }\end{array}$ & $\mathrm{x}$ & $\mathrm{x}$ & $\mathrm{x}$ & $\mathrm{x}$ & 0 & 68.86 & 21.83 & 7.89 & 0.50 & 2 & 34.71 & 2 \\
\hline C. huetii & 21 & 73.64 & 107.3 & 1 & 0 & 269.87 & 41.89 & 15.21 & 0.21 & 2 & 58.18 & 0 \\
\hline C. mathiolifolia & 14 & 55.93 & 107.9 & 1 & 0 & 257.08 & 40.01 & 14.26 & 0.21 & 2 & 54.83 & 0 \\
\hline C. germanicopolitana & 16 & 95.15 & 162.33 & 1 & 0 & 268.47 & 40.42 & 21.85 & 0.12 & 3 & 33.87 & 3 \\
\hline C. depressa & 16 & 101.94 & 130.21 & 1 & 0 & 230.03 & 39.81 & 13.55 & 0.15 & 2 & 34.97 & 0 \\
\hline C. pinardii & 17 & 68.20 & 82.46 & 1 & 0 & 354.67 & 70.98 & 25.33 & 0.20 & 2 & 72.62 & 0 \\
\hline C. tchihatcheffii & 21 & 50.79 & 56.45 & 0 & 0 & 236.21 & 53.20 & 18.8 & 0.14 & 2 & 34.83 & 2 \\
\hline C. cyanus $\mathrm{L}$. & 16 & 81.97 & 145.26 & 1 & 0 & 217.05 & 47.30 & 17.80 & 0.17 & 2 & 38.25 & 3 \\
\hline
\end{tabular}

\section{Results and Discussion}

\section{Stem anatomy}

The stem cross-section varied in size among the species (Table 3). In most, it was oval-shaped with leaf blade parts (Figs 1-5). In the examined species, the stems were densely covered by unicellular trichomes (Figs 1-5). Collenchyma was present at protrusion areas in stem crosssections. Cortex parenchyma had two types of cells; the first was cylindrical-shaped with abundant chlorophyll, the second was oval-shaped with less chlorophyll. Sclerenchyma was placed above the phloem in the cortical parenchyma of most of the species.

In all of the species examined, vascular bundles were collateral type, forming either continuous or discontinuous rings, arcs, or rings with arcs inside (Figs 1-5). Sclerenchymatic caps were found around the vascular bundles in the examined species, except in $C$. tchihatcheffii, $C$. woronowii, and $C$. thirkei (Figs 1,3,4). Vascular bundles were observed near the abaxial surface of the stems and varied in number among the species. 

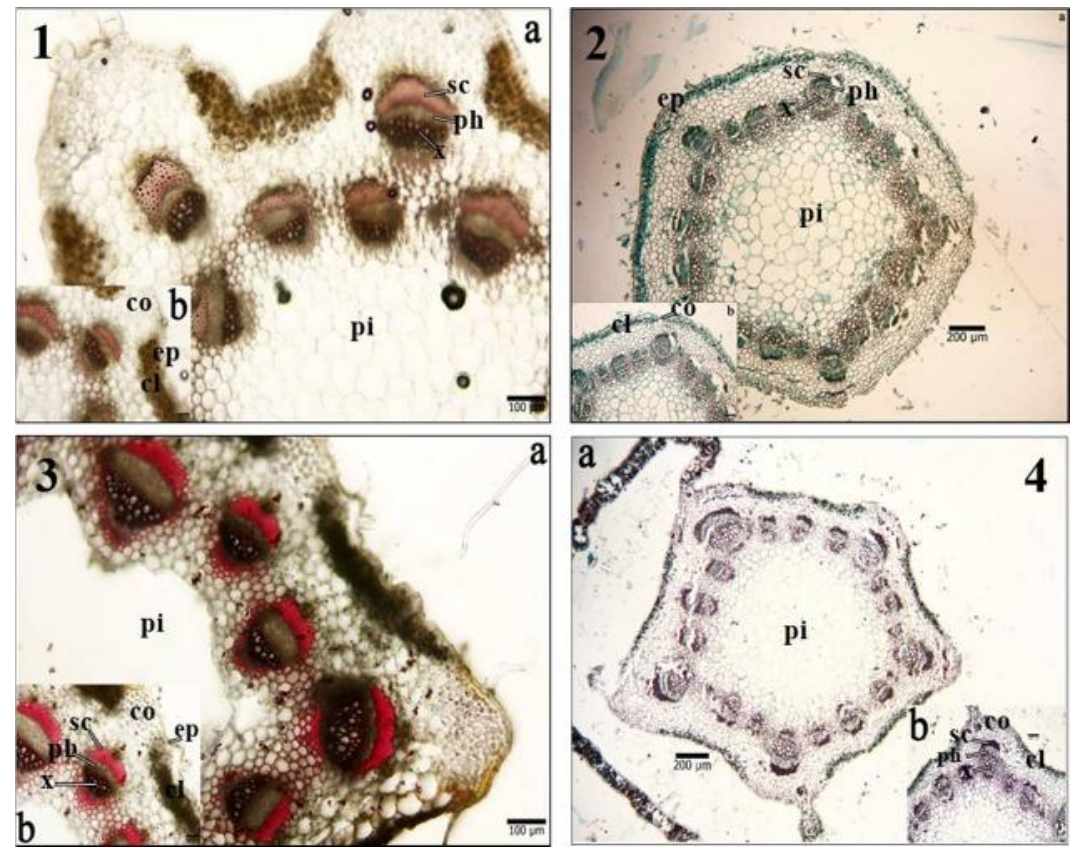

Fig. 1. The stem anatomical photographs of Cyanus subgenus. (a) general view, (b) close view 1. C. reuteriana var. reuteriana 2. C. reuteriana var. phyrgia, 3. C. lanigera, 4. C. nigrofimbria. ep:epidermis, cl:chlorenchyma, co:collenchyma, sc:sclerenchyma, ph:phloem, x:xylem, pi:pith
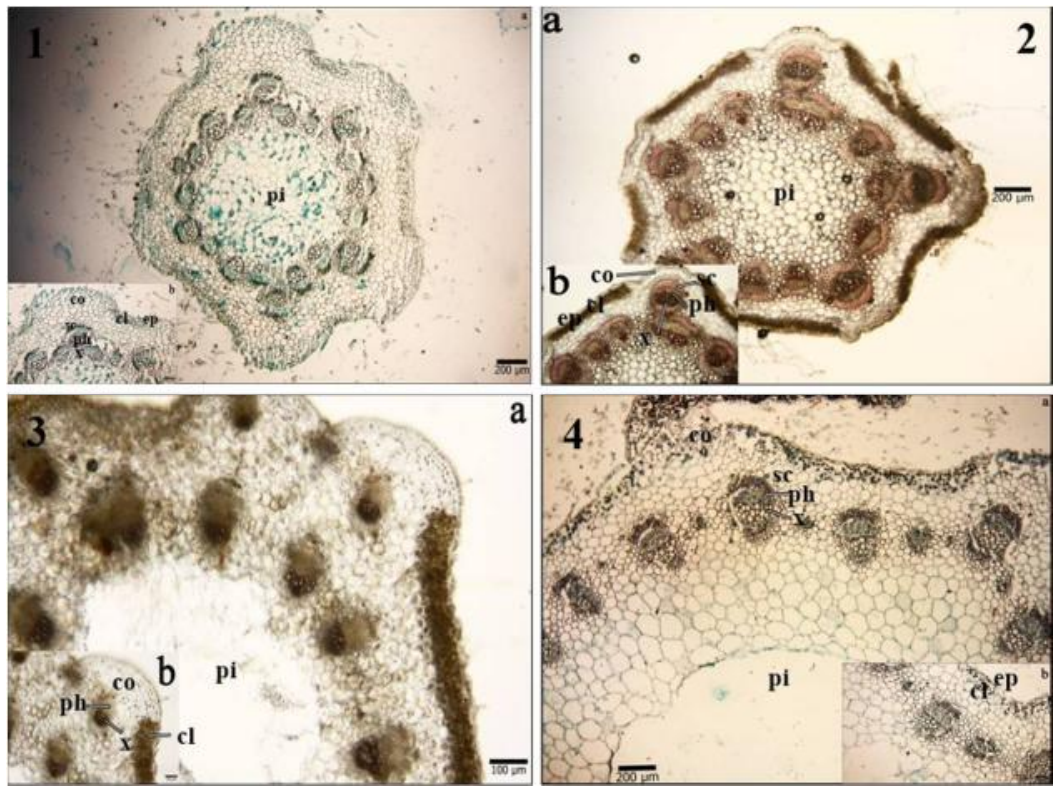

Fig. 2. The stem anatomical photographs of Cyanus subgenus. (a) general view, (b) close view 1. C. woronowii, 2. C. eflanensis, 3. C. thirkei, 4. C. bourgaei. ep:epidermis, cl:chlorenchyma, co:collenchyma, sc:sclerenchyma, ph:phloem, $\mathrm{x}: x y l e m$, pi:pith 

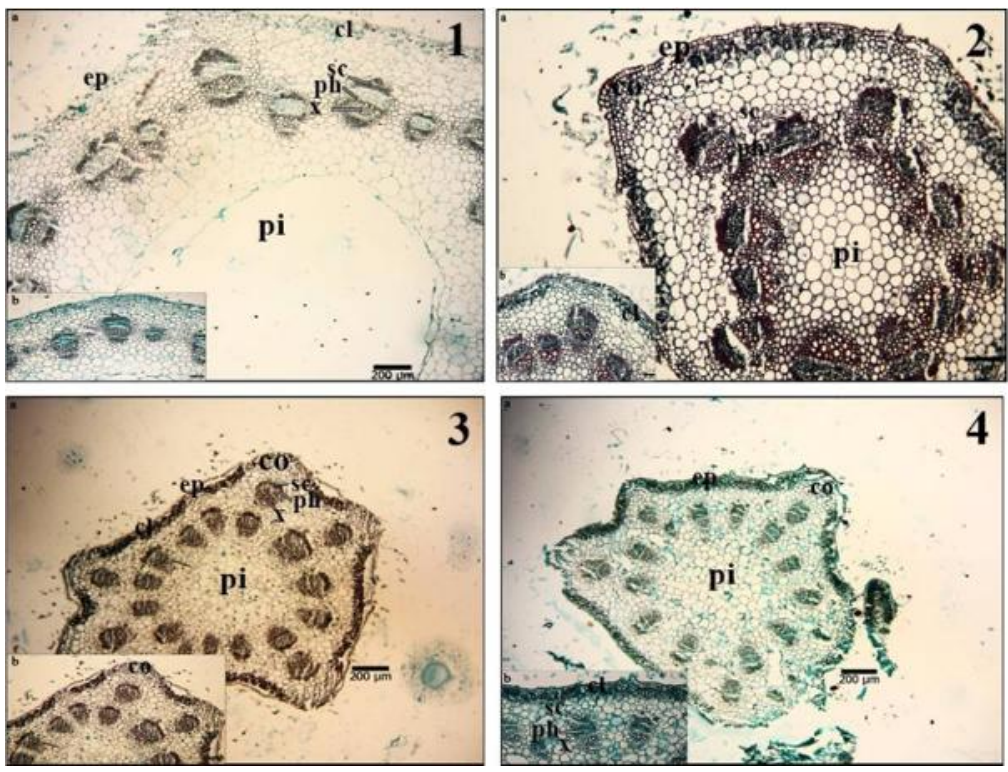

Fig. 3. The stem anatomical photographs of Cyanus subgenus. (a) general view, (b) close view. 1. C. cheiranthifolia var. cheiranthifolia, 2. C. cheiranthifolia var. purpurascens 3. C. pichleri subsp. pichleri 4. C. pichleri subsp. extrarosularis. ep:epidermis, cl:chlorenchyma, co:collenchyma, sc:sclerenchyma, ph:phloem, x:xylem, pi: pith

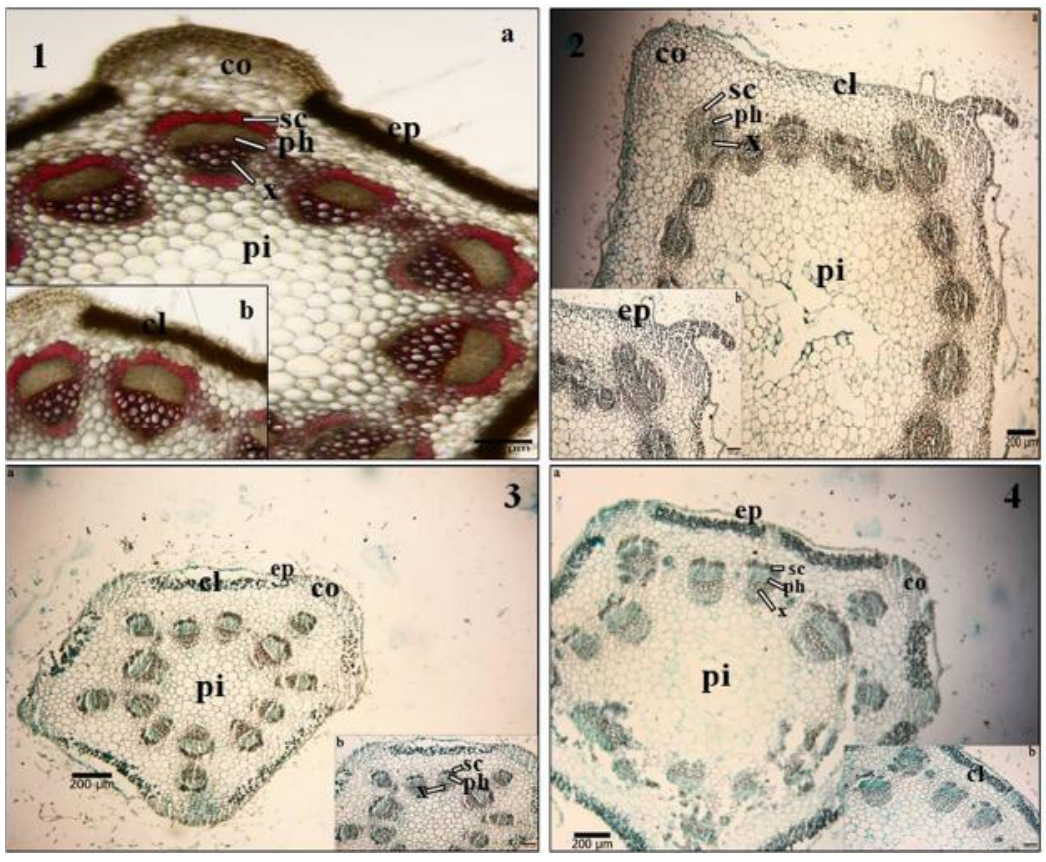

Fig. 4. The stem anatomical photographs of Cyanus subgenus. (a) general view, (b) close view. 1. C. triumfetti subsp. axillaris, 2. C. huetii, 3. C. mathiolifolia, 4. C. germanicopolitana. ep:epidermis, cl:chlorenchyma, co:collenchyma, sc:sclerenchyma, ph:phloem, x:xylem, pi:pith 

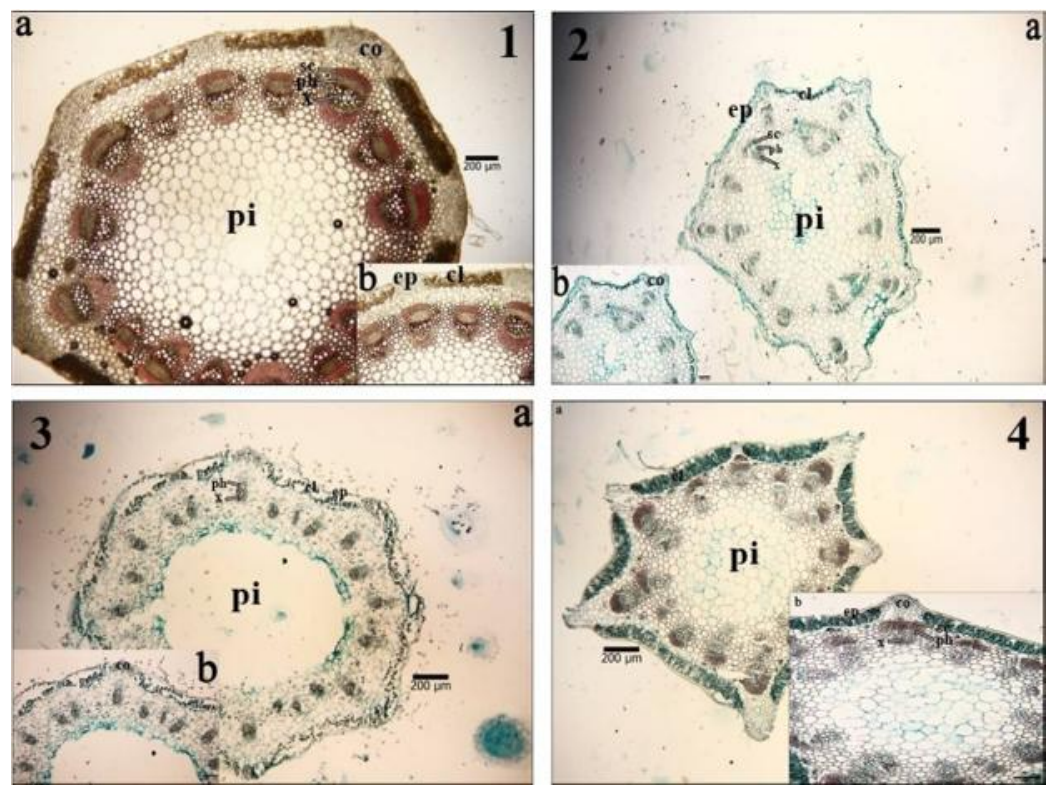

Fig. 5. The stem anatomical photographs of Cyanus subgenus. (a) general view, (b) close view. 1. C. depressa, 2. C. pinardii, 3. C. tchihatcheffii, 4. C. cyanus. ep:epidermis, cl:chlorenchyma, co:collenchyma, sc:sclerenchyma, ph:phloem, x:xylem, pi:pith
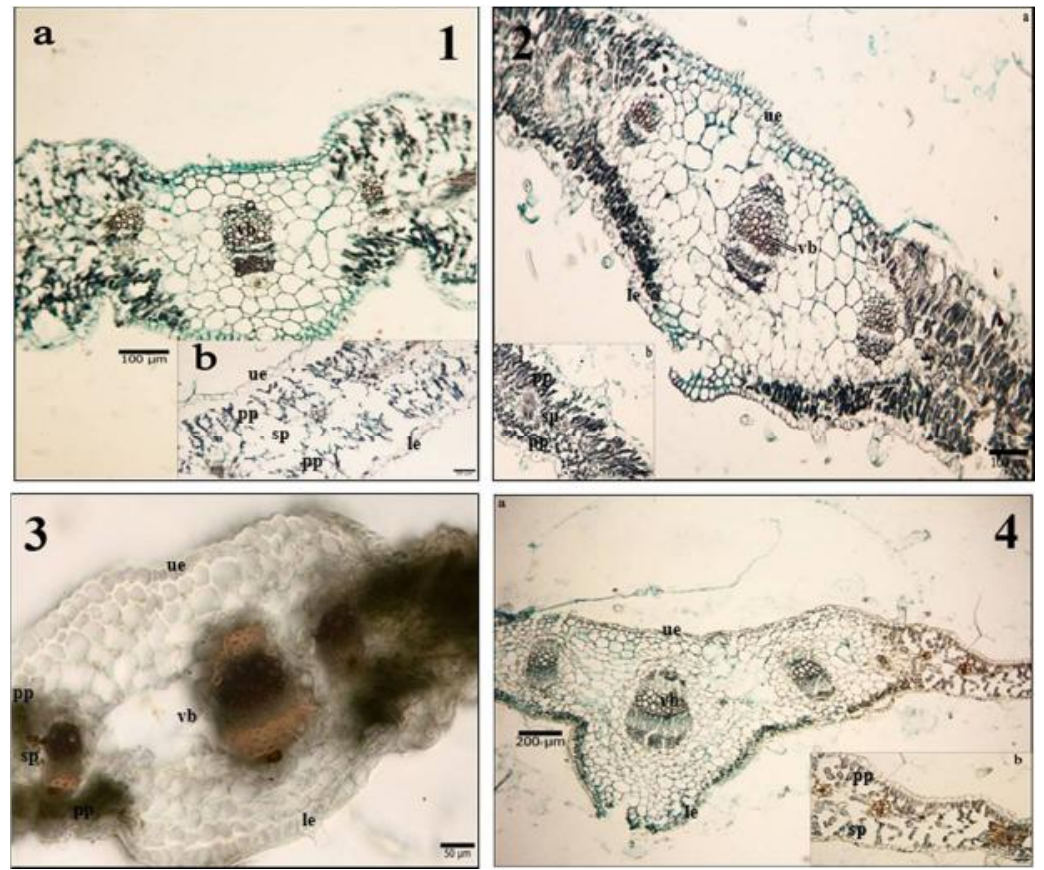

Fig. 6. The leaf anatomical photographs of Cyanus subgenus. (a) general view of midrib, (b) lamina view. 1. C. reuteriana var. reuteriana, 2. C. reuteriana var. phyrgia, 3. C. lanigera, 4. C. nigrofimbria. ue: upper epidermis, le:lower epidermis, pp:palisade parenchyma, sp: spongy parenchyma, vb:vascular bundle 


\section{Leaf blade and Midrib}

The shape of the epidermal cells from the adaxial face was either rectangular or oval (Figs 610). The epidermis was uniseriate in all of the species. Collenchyma occurred under the midrib epidermis in all of the species. The mesophyll was equifacial in 17 species with well-defined palisade and reduced spongy parenchyma, bifacial in three species: $C$. woronowii, $C$. nigrofimbria, and $C$. reuteriana var. phrygia (Figs 6 and 7). Palisade parenchyma was composed of two to three layers of elongated cylindrical cells (Table 3 ). Cells of spongy parenchyma were predominantly cuboid, variably compressed according to the species. Only three species were characterized by loose spongy parenchyma, with larger intercellular spaces. Stomata were observed at the level of the epidermal line (Figs 6-10) in the species.

Midrib shape in cross-sectional view also varied among the species (Figs 6-10). On the abaxial side, it was convex in all of the species. On the adaxial side, convex (Figs 6,7,9), concave (Figs 6, 8,10), and planar midribs were found (Figs 6,8,9,10). The midrib vascular system was organized into arches that were formed by collateral bundles arranged in groups of 1 or 3 .

\section{Statistical analysis}

The dendrogram derived from the cluster analysis using the UPGMA based on the nine anatomical variables of the 20 Cyanus species is presented in Fig. 11, in which the similarities among the examined species were presented. The dendrogram revealed two main groups: Groups A and B. Group A (with 58\% similarity) comprised one perennial plant, C. reuteriana var. phrygia. Group B (with 62\% similarity) comprised the remaining 19 taxa of the annuals and perennials of Turkish Cyanus. Group B consisted of two main clusters, which were described further as Clusters B1 and B2. Cluster B1 included C. germanicopolitana and C. reuteriana var. reuteriana (with $72 \%$ similarity). Group $\mathrm{C}$ consisted of only $C$. triumfetti subsp. axillaris. Cluster D included two main clusters: Clusters D1 and D2. Cluster D1 included two species: $C$. cheirantifolia var. purpurascens and C. pinardii. D2 contained two main clusters: Groups E and F. Group E consisted of two species C. nigrofimbria and C. woronowii (with $84 \%$ similarity). Cluster F included 10 species in two different subclusters: F1 and F2. Sub-cluster F1 comprised two further subclusters: Groups $\mathrm{G}$ and $\mathrm{H}$. Group $\mathrm{G}$ contained only $C$. lanigera. Group H included two subclusters: Group $\mathrm{H} 1$ and $\mathrm{H} 2$. Group $\mathrm{H} 1$ contained $C$. eflanensis, $C$. pichleri subsp. extrarosularis, and C. cyanus (with $88 \%$ similarity) under two different subclusters. Group F2 included two subclusters, namely Subclusters F3 and F4. Subcluster F3 contained only $C$. cheiranthifolia var. cheiranthifolia. Subcluster F4 comprised C. matthiolifolia and C. huetii and C. depressa under two different smaller subclusters (with 93\% similarity).

The anatomical findings on the subgenus Cyanus herein supported the results of Sirin et al. (2017), Sirin et al. (2019), and Citak et al. (2021), from the point of view of the karyological, palynomorphological, and achene morphological data.

The stem anatomical characters were determined to vary among the species; however, patterns allowing distinctions among species were not detected. Çakırlar et al. (2005) presented differences in the vascularization patterns of the stems of $C$. tchihatcheffii and $C$. depressa, including variations in the vascular bundle type, and number and position of accessory bundles (Fig. 5). The shape of the stem cross-sections was rounded, semi-rounded, rectangle, circular, or irregular in the family Asteraceae (Celik et al., 2005, 2008; Aydin et al., 2013; Aydin et al., 2019) and also in the subgenus Cyanus (Çakırlar et al., 2005, Özcan et al., 2014, Özcan, 2018). The position and the number of layers of the collenchyma tissue are important in plant communities (Metcalfe and Chalk, 1950; Özörgücü et al., 1991; Lersten and Curtis, 1997; Makbul et al., 2008, Aydin et al., 2013, Özcan et al., 2014). In current study, it was observed that different rows of collenchymatic tissue (3-10 rows) were located under epidermis. The arrangement of the vascular 

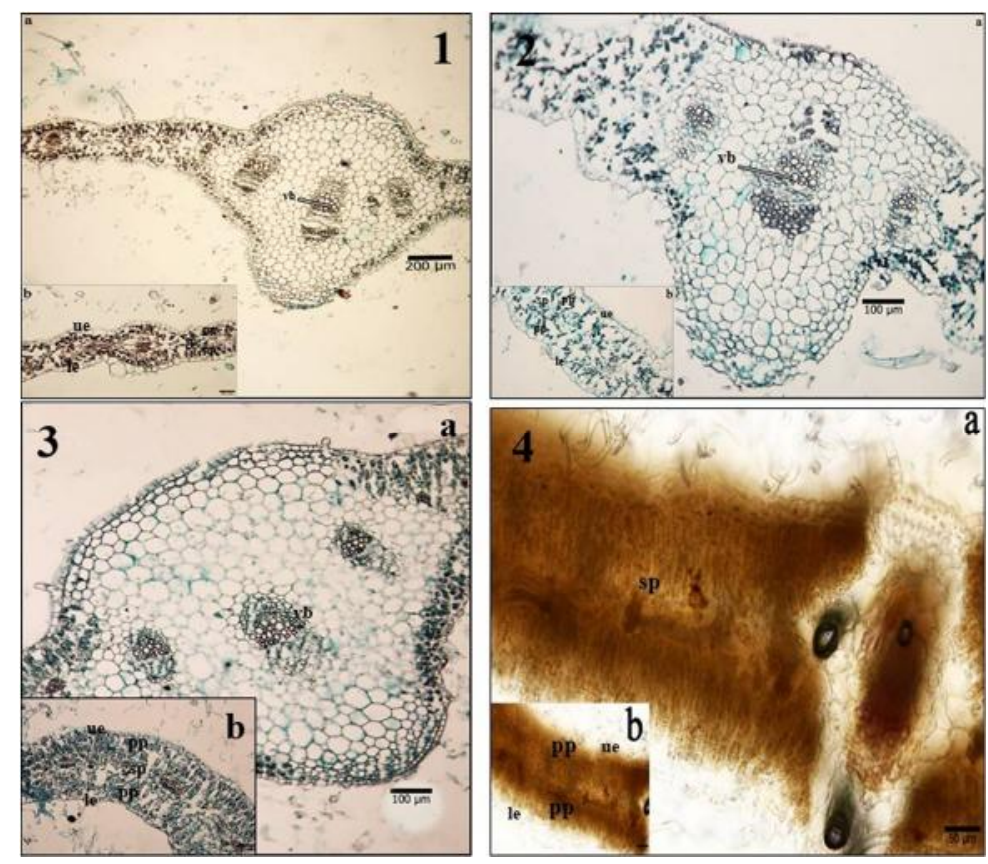

Fig. 7. The leaf anatomical photographs of Cyanus subgenus. (a) general view of midrib, (b) lamina view. 1. C. woronowii, 2. C. eflanensis, 3. C.thirkei, 4. C. bourgaei. ue: upper epidermis, le:lower epidermis, pp:palisade parenchyma, sp: spongy parenchyma, vb:vascular bundle
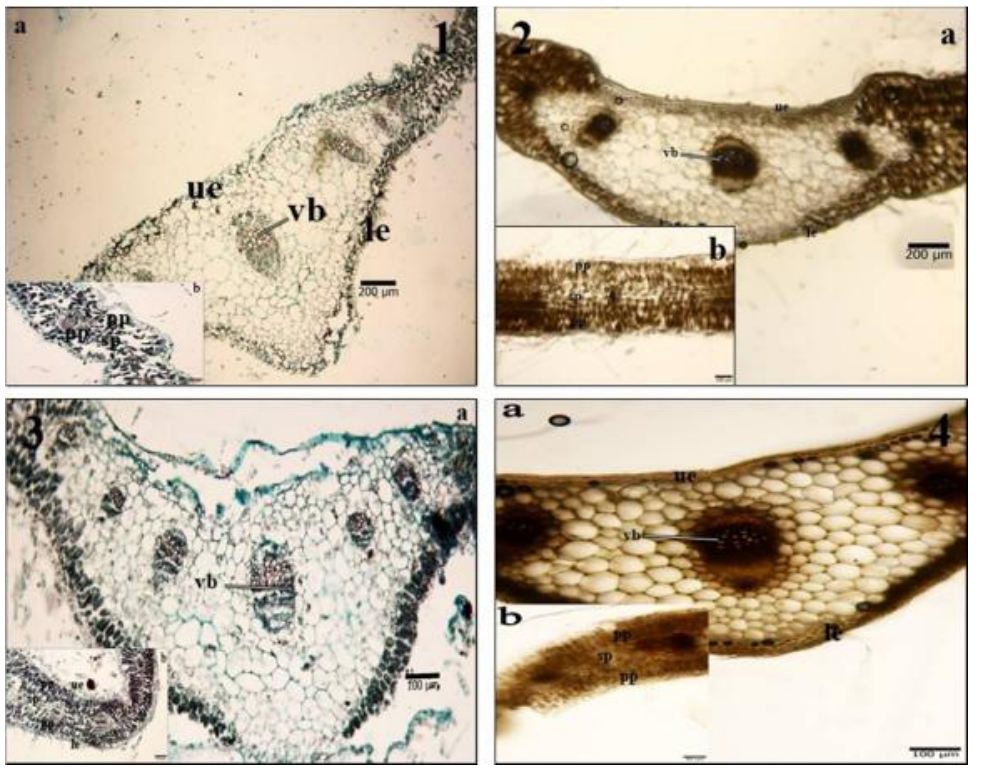

Fig. 8. The leaf anatomical photographs of Cyanus subgenus. (a) general view of midrib, (b) lamina view. 1. C. cheiranthifolia var. cheiranthifolia, 2. C. cheiranthifolia var. purpurascens, 3. C. pichleri subsp. pichleri, 4. C. pichleri subsp. extrarosularis. ue: upper epidermis, le:lower epidermis, pp:palisade parenchyma, sp: spongy parenchyma, vb:vascular bundle 

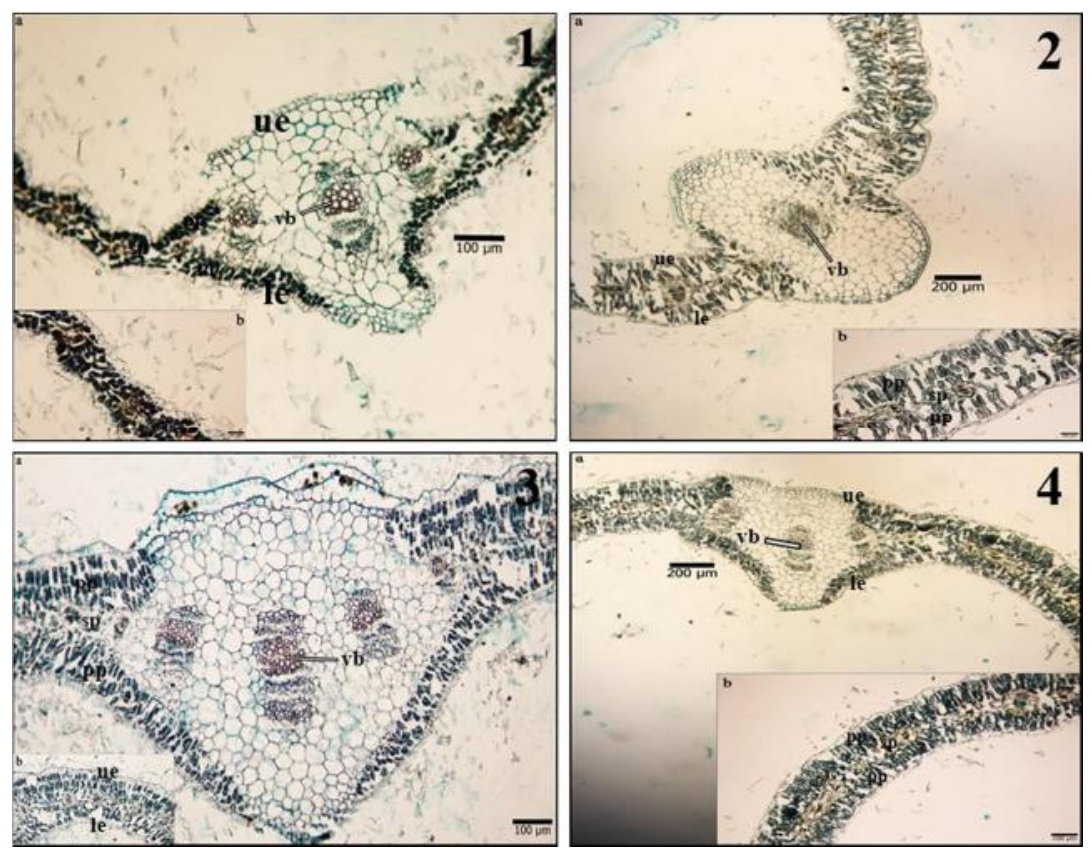

Fig. 9. The leaf anatomical photographs of Cyanus subgenus. (a) general view of midrib, (b) lamina view. 1. C. triumfetti subsp. axillaris, 2. C. huetii, 3. C. mathiolifolia, 4. C. germanicopolitana. ue: upper epidermis, le:lower epidermis, pp:palisade parenchyma, sp: spongy parenchyma, vb:vascular bundle.
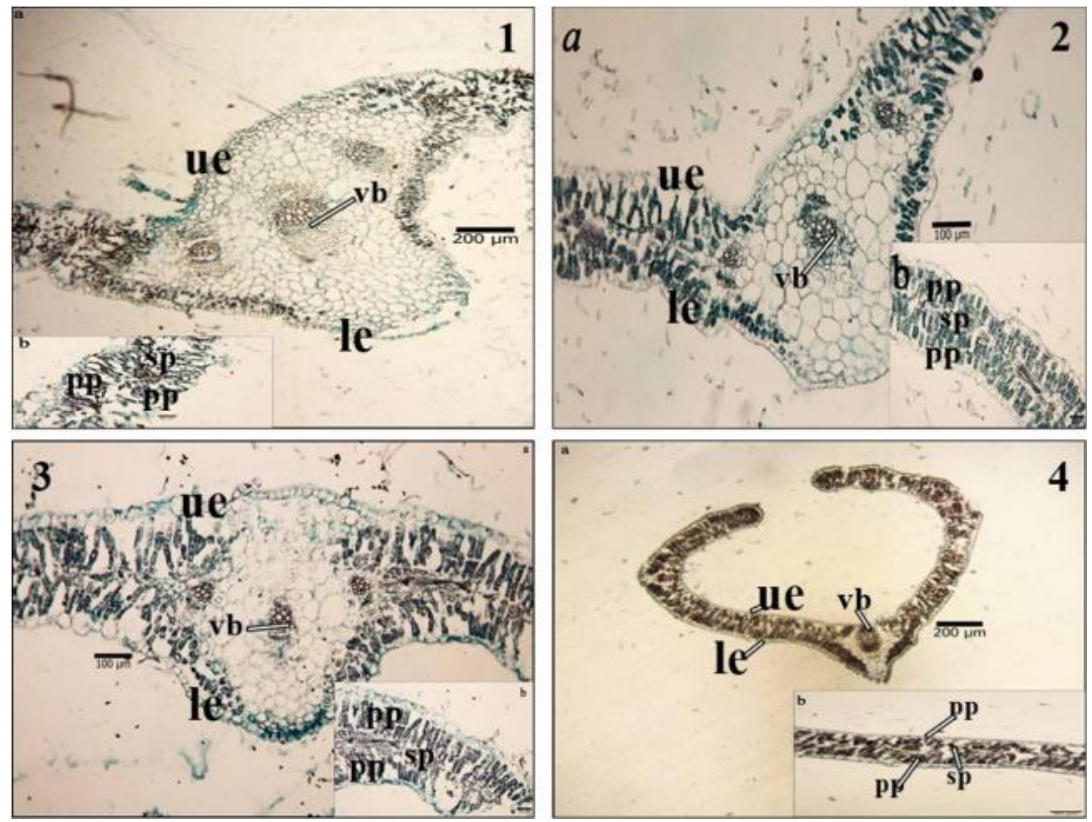

Fig. 10. The leaf anatomical photographs of Cyanus subgenus. (a) general view of midrib, (b) lamina view. 1. C. depressa, 2. C. pinardii, 3. C. tchihatcheffii, 4. C. cyanus. ue: upper epidermis, le:lower epidermis, pp:palisade parenchyma, sp: spongy parenchyma, vb:vascular bundle. 


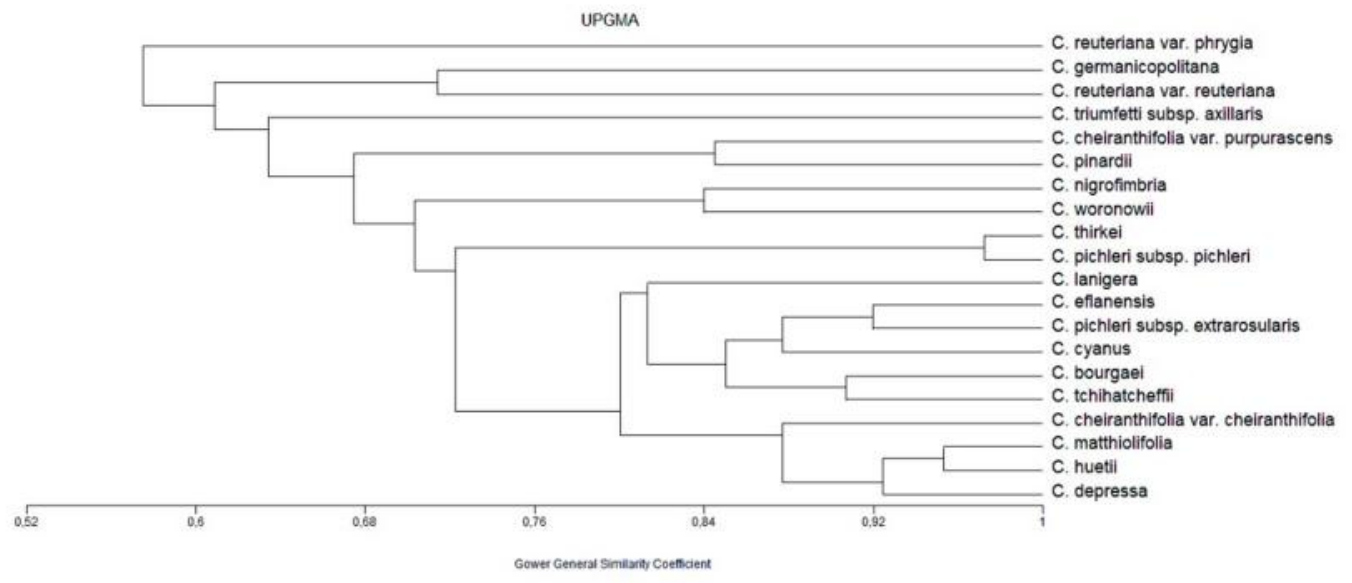

Fig. 11. The combined dendrogram according to anatomical characters of Cyanus subgenus

bundles was found to be in an arc shape in all of the studied species of the subgenus Cyanus by Çakırlar et al. (2005), Özcan et al. (2014), Özcan (2018) prior to this study. In the current study, this phenomenon was confirmed. The vascular bundles in the stem were generally arranged as two rings, and especially, those found under the collenchymatic area were bigger than the other vascular bundles. Celik et al. $(2005,2008)$ and Kaya et al. (2010) reported that the vascular bundles were scattered in a circular manner as one ring in the stem of some species of Centaurea. Clustered sclerenchymatic fibers were located on the upper sides of the vascular bundles in the examined taxa, except in C. tchihatcheffii, C. woronowii, and C. thirkei (Figs 2 and 5). Additionally, a chlorenchymatous tissue below the epidermis was observed in the stem cortex in the examined species. This kind of tissue was reported for the genus Centaurea in some previous studies performed by Uysal et al. (2005), Celik et al. (2005, 2008), and Kaya et al. (2010), and the subgenus Cyanus by Çakırlar et al. (2005), Özcan et al. (2014), and Özcan (2018). The stem cortex usually consisted of parenchymatic oval cells with thin walls in all of the examined taxa, but it varied from two to four rows.

It was found that the mesophyll of 17 species were equifacially oriented, with well-developed palisade parenchyma and reduced spongy parenchyma, and in contrast three species were dorsiventrally oriented. According to the observations of Özcan et al. (2014), the mesophyll of $C$. cheiranthifolia var. purpurascens and $C$. woronowii were equifacial. The present study confirmed that this was true of the mesophyll of $C$. cheiranthifolia var. purpurascens (Fig. 8); however, it was not true for $C$. woronowii (Fig. 7).

In the present study, dorsiventral mesophyll was only observed in $C$. woronowii (Fig. 7), $C$. nigrofimbria (Fig. 6), and C. reuteriana var. phrygia (Fig. 6) which grow in moist areas, while equifacial leaves were observed in the other investigated taxa, which mainly grow in the dry habitats of the Irano-Turanian phytogeographic region of Turkey. According to Yentür (2003), equifacial leaves were generally characteristic of xerophytic plants, which was in accordance with the observations made herein.

The varying midrib shape in Cyanus species can really contribute the systematics of this subgenus. Özcan et al. (2014) and Özcan (2018) reported that there were three vascular bundles in the midrib of $C$. cheiranthifolia var. purpurascens and C. nigrofimbria, and six in C. woronowii, which was in agreement with the results of the current study. 
The UPGMA dendrogram derived from the anatomical traits of the stem and leaf discriminated the species of the subgenus Cyanus (Fig. 11). The positions of Cyanus species and their similarities reflected in the clusters were found to be partially agreeable with the previous classification of the subgenus based on the morphological data. C. nigrofimbria and C. woronowii were in the same clade according to their mesophyll type. The subspecies and varieties were close to each other in the dendrogram; however, their different positions in the different clusters can be explained by different ecological habitats, such as dry areas or forest ecosystems.

In conclusion, the number of vascularization patterns in stems, mesophyll type, and midrib shape were the most valuable variables for distinguishing the species of the subgenus Cyanus. The foliar and stem anatomical characters can help to improve the knowledge on Cyanus, separate its species more effectively, remerge the taxa, and provide an important database for future phylogenetic research within the group.

\section{Acknowledgments}

The authors wish to thank the Financial Unit of Selçuk University for their support of this study (Project no: 20401103).

\section{References}

Altundağ, E. and Gürdal, B. 2009. Anatomical characteristics of Centaurea glastifolia L. (Asteraceae) used as folk medicine in East Anatolia, Istanbul J. Pharm. 40: 57-64.

Aydin, Ö., Coşkunçelebi, K., Gültepe, M. and Güzel., M. E. 2013. A contribution to taxonomy of Centaurea including Psephellus (Asteraceae) based on anatomical and molecular data, Turk J Bot. 37: 419-427.

Aydın, R., Dural, H. and Çıtak, B.Y. 2019. Centaurea cheirolopha (Fenzl) Wagenitz ve Centaurea lycopifolia Boiss. \& Kotschy (Asteraceae) Taksonlarının Anatomik ve Mikromorfolojik Karakterlerinin İncelenmesi, Erzincan Üniversitesi Fen Bilimleri Enstitüsü Dergisi 12(3): 1341-1355 (in Turkish).

Bentham, G. 1873. Compositae. In: Bentham, G., Hooker, J. D. (Eds.), Genera Plantarum. Lovell reeve \& co., London, pp. 162-533.

Bhattacharya, B. and Johri, B.M. 1998. Flowering Plants, Taxonomy and Phylogeny, Springer-Verlag, pp. $526-529$.

Boršić, I., Susanna, A., Bancheva, S. and Garcia-Jacas, N. 2011. Centaurea sect. Cyanus: Nuclear phylogeny, biogeography, and life-form evolution, Int. J. Plant Sci. 172: 238-249.

Çakırlar, N., Çiçek, N., Topaloğlu, S. and Bursalı, B. 2005. Ankara-Gölbaşı'nda yetişen endemik Centaurea tchihatcheffii Fisch. et. Mey. ve aynı bölgede yer alan Centaurea deprassa'nın anatomik Özellikleri. In: Boşgelmez, A. (Ed.), Centaurea tchihatcheffii Ankara-Gölbaşı sevgi çiçeği, Bizim büro basımevi, Ankara, pp. 259-278 (in Turkish).

Celik, S., Uysal, T. and Menemen, Y. 2008. Morphology, anatomy, ecology and palynology of two Centaurea species from Turkey, Bangladesh J. Bot. 37: 67-74.

Celik, S., Uysal, T., Menemen, Y. and Karabacak, E. 2005. Morphology, anatomy, ecology, pollen and achene structure of Centaurea consanguinea DC. (Sect. Acrolophus) in Turkey, Int. J. Botany 1: 85-89.

Citak, B.Y., Sirin, E., Dural, H. and Ertuğrul, K. 2021. Usefulness of palynomorphological characteristics for the identification of species Cyanus Mill. (Asteraceae) in Turkey: a taxonomic approach, Turk J Bot. 45(1): 43-58.

De Candolle, A. P. 1838. Centaurea In: Prodromus systematis naturalis regni vegetabilis. Treuttel \& Würtz, Paris. 6, pp. 565-605.

Ertuğrul, K., Şirin, E. and Uysal, T. 2018. Taxonomic revision of subgenus Cyanus (Centaurea, Asteraceae). Abstract book of 1st International Congress on Plant Biology, Konya, 19 pp.

Esau, K. 1977. Anatomy of Seed Plants. 2'ed. New York.

Greuter, W. 2003. The Euro+Med treatment of Cardueae (Compositae) - generic concepts and required new names, Willdenowia 33: 49-61. 
Greuter, W. 2008. Med-checklist: A critical inventory of vascular plants of the circum-Mediterranean countries 2. Dicotyledones (Compositae). OPTIMA, Palermo et Conservatoire Botanique de la Ville de Genève, Geneva.

Gower, J.C. 1971. A general coefficient of similarity and some of its properties, Biometrics 27: 857-871.

Hellwig, F. H. 2004. Centaureinae (Asteraceae) in the Mediterranean - history of ecogeographical radiation, Plant Sys Evo. 246: 137-162.

Hilpold, A., García-Jacas, N., Vilatersana, R. and Susanna, A. 2014a. Taxonomical and nomenclatural notes on Centaurea: A proposal of classification, a description of new sections and subsections, and a species list of the redefined section Centaurea, Collect Bot. 33:1-29.

Hilpold, A., Vilatersana, R., Susanna, A., Meseguer, A. S., Boršıc, I., Constantınıdıs, T., Filigheddu, R., Romaschenko, K., Suarez-Santıgo, V. N., Tugay, O., Uysal, T., Pfe1l, B. E. and Garcia-Jacas, N. 2014b. Phylogeny of the Centaurea group (Centaurea, Compositae)-geography is a better predictor than morphology, Mol. Phylogenet. Evol. 77: 195-215.

Janaćković, P., Gavrilović, M., Rančić, D., Dajić- Stevanović, Z., Giweli, A. A. and Marin, P. D. 2019a. Comparative anatomical investigation of five Artemisia L. (Anthemideae, Asteraceae) species in view of taxonomy, Braz J Bot. 42(1): 135-147.

Janaćković, P., Sussana, A. and Marin, P. D. 2019b. Micromorphology and anatomy in systematics of Asteraceae An old-fashioned approach, Biol Nyssana. 10(2): 77-85.

Johansen, D. A. 1940. Plant Microtechnique, New York, McGraw-Hill, 523 pp.

Kaya, Z., Orcan, N., Binzet, R. and Genç, Y. 2000. The exterior-interior morphological characteristics and the palynological properties of endemic Centaurea zeybekii Wagenitz. Second Balkan Botanical Congress, Istanbul.

Lersten, N.R. and Curtis, J.D. 1997. Anatomy and distribution of foliar idioblasts in Scrophularia and Verbascum (Scrophulariaceae), Am J Bot. 84: 1638-1645.

Makbul, S., Türkmen, Z., Coskunçelebi, K. and Beyazoglu, O. 2008. Anatomical and pollen characters in the genus Epilobium L. (Onagraceae) from Northeast Anatolia, Acta Biol Cracov Bot. 50: 57-67.

Metcalfe, C. R. and Chalk, L. 1950. Anatomy of the Dicotyledons, II. Oxford University Press.

Metcalfe, C. R. and Chalk, L. 1957. Anatomy of the Dicotyledons. Clarendon Press, Oxford.

Metcalfe, C. R. and Chalk, L. 1979. Anatomy of Dicotyledones I, Oxford. University Press, pp. 783-803.

Miller, P. 1754. The gardeners dictionary, abr, John \& James Rivington, London.

Negaresh, K. 2018. A new combination in the genus Cyanus (Asteraceae: Cardueae, Centaureinae), Candollea 73: 101-104.

Olšavská, K., Perný, M., Kučera, J. and Hodalova, I. 2011. Biosystematic study of the Cyanus triumfetti group in Central Europe, Preslia 83: 99-110.

Olšavská, K., Perný, M., Mártonfi, P. and Hodálová, I. 2009. Cyanus triumfetti subsp. triumfetti (Compositae) does not occur in the western Carpathians and adjacent parts of Pannonia: karyological and morphological evidence, Nord J Bot. 27: 21-36.

Özcan, M. 2018. Anatomical and micromorphological investigations on some Centaurea Asteraceae, Cardueae taxa from NE Anatolia, Biodicon 11(2): 29-41.

Özcan, M. 2013. Türkiye' de Yetişen Psephellus pulcherrimus (syn: Centaurea pulcherrima var. freynii) (Cardueae, Asteraceae)' un Morfolojik ve Anatomik Özellikleri, ACU J For Fac. 14(1): 104-112 (in Turkish).

Özcan, M., Unver, M. C. and Eminagaoglu, O. 2014. Comparative anatomical and ecological investigations on some Centaurea (Asteraceae) taxa from Turkey and their taxonomic significance, Pak J Bot. 46(4): 1287-1301.

Özörgücü, B., Gemici, Y. and Türkan, I. 1991. Karşılaştırmalı Bitki Anatomisi. İzmir: Ege Üniversitesi Fen Fakültesi Yayını (in Turkish).

Şirin, E., Ertuğrul, K. and Uysal, T. 2017. Achene micromorphology of the genus Cyanus Mill. (Compositae) in Turkey and its taxonomic importance, Phytotaxa 313: 77-90.

Şirin, E., Bozkurt, M., Uysal, T. and Ertuğrul, K. 2019. Karyomorphological features of Turkish Centaurea (Subgenus Cyanus/Asteraceae) species and its taxonomic importance, Turk J Bot. 43(4): 538-550.

Sneath, P.H. and Sokal, R.R. 1973. Numerical taxonomy. The principles and practice of numerical classification. W.H. Freeman \& Co.,San Francisco, 573 pp. 
Soják, J. 1972. Nomenklatorické poznámky (Phanerogamae). Časopis Národního Musea. Oddíl př́rodovědný 140: $127-134$.

Stefanov, B. and Gheorghiev, T. 1931. Contribution to distinction of the species of genus Centaurea (L.) sect. Cyanus (DC.), Proceeding of the Bulgarian Academy of Sciences 44: 133-193.

Stoyanov, S.S. 2016. Reinstatement of Centaurea cyanomorpha (Asteraceae), an endemic species from southeastern Bulgaria. Phytotaxa 268: 46-56.

Susanna, A. and Garcia-Jacas, N. 2009. Cardueae (Carduoideae). In: Funk, V.A., Susanna, A., Stuessy, T.F., Bayer, R.J. (Eds.), Systematics, Evolution, and Biogeography of Compositae. International Association for Plant Taxonomy, Vienna, pp. 293-313.

Taşar, N., Doğan, G., Kıran, Y., Rahman, M. O. and Çakılcığlu, U. 2018. Morphological, anatomical and cytological investigations on three taxa of Centaurea L. (Asteraceae) from Turkey, Bangl J Plant Taxon. 25(2): 215-226.

Uysal, I. 1991. Tripleurospermum baytopianum E. Hossain ve Centaurea polyclada DC. endemik türlerinin morfolojisi, anatomisi ve ekolojisi üzerine araştırmalar, Anadolu Üniversitesi Fen-Edebiyat Fakültesi Dergisi 3: 37-51 (in Turkish).

Uysal, I., Celik, S. and Menemen, Y. 2005. Morphology, anatomy, ecology, pollen and achene features of Centaurea polyclada DC. (Sect. Acrolophus) in Turkey, J. Biol. Sci. 5: 176-180.

Wagenitz, G. 1975. Centaurea L. in: Davis, PH (Ed.), Flora of Turkey and the east Aegean Islands. Vol. 5. Edinburgh University Press, Edinburgh, pp. 465-585.

Wagenitz, G. 2006. A revision of Centaurea (Compositae-Cardueae) in the flora of Iraq. -Rostaniha, 7 (suppl. 2): 343-394.

Yentür, S. 2003. Bitki Anatomisi. İstanbul Üniversitesi Fen Fakültesi Yayınları, İstanbul (In Turkish). 